\title{
A CARTA DAS NAÇÕES UNIDAS E A SOLUÇÃO PACÍFICA DAS CONTROVÉRSIAS INTERNACIONAIS ${ }^{1}$
}

\author{
THE CHARTER OF THE UNITED NATIONS AND THE PACIFIC SETTLEMENT OF INTERNATIONAL \\ DISPUTES
}

Bruno Graça Simões ${ }^{2}$

\begin{abstract}
Resumo
O Autor trata das disposições da Carta das Nações aplicáveis ao tema da solução pacífica de controvérsias internacionais, dando ênfase inicialmente à estrutura lógica dos propósitos e princípios da Carta e apresentando uma breve observação preliminar sobre a Corte Internacional de Justiça. O Autor desenvolve, a seguir, considerações sobre a atuação do Conselho de Segurança das Nações Unidas, da Assembléia Geral das Nações Unidas e do Secretariado, tendo em vista suas competências gerais, suas competências específicas e o efeito de suas intervenções do ponto de vista teórico e prático.
\end{abstract}

Palavras-chave: Carta das Nações Unidas. ONU. Solução Pacífica de Controvérsias. Conselho de Segurança.

\begin{abstract}
The Author deals with the provisions contained in the Charter of the United Nations that are concerned with the theme of peaceful settlement of international disputes, by emphasizing firstly the logical structure of the Charter's purposes and principles and presenting a short consideration about the International Court of Justice. The Author develops further considerations on the role of the United Nations Security Council, the United Nations General Assembly and the Secretariat, always in a view of their general competences, specific competences and the effects of their actions in a theoretic and pragmatic point of view.
\end{abstract}

Keywords: Charter of the United Nations. UN. Dispute Settlement. UN Security Council

\footnotetext{
- O presente artigo é uma breve reflexão baseada em trabalhos de pesquisa conduzidos durante nossa graduação tanto na forma de monografia de iniciação científica quanto na forma de tese de láurea. O Autor agradece o apoio material recebido das diversas esferas da Universidade de São Paulo através do Programa Institucional de Bolsas de Iniciação Científica, através do Programa Jovem Jurista e através do programa de intercâmbio acadêmico que viabilizou nossa estadia em Genebra durante o mês de julho de 2006 para conclusão das referidas pesquisas. O Autor agradece ainda todo o apoio dos professores Celso Lafer, João Grandino Rodas, Walküre Lopes Ribeiro da Silva, Umberto Celli Júnior e Elizabeth Meirelles na viabilização, preparação, orientação e revisão dos estudos que culminariam neste artigo, sendo apenas nossa, no entanto, a responsabilidade por seu conteúdo.

2 Mestrando em Direito Internacional pela Faculdade de Direito da Universidade de São Paulo.
} 
1. Introdução

A Carta das Nações Unidas começou a ser redigida ainda durante a Segunda Guerra Mundial. As proporções inéditas do conflito causaram justificada comoção em todos aqueles que o vivenciaram. O impacto emocional do violento associado aos pendores liberais de boa parte das Nações Aliadas fez surgir a noção de conservação responsável da ordem internacional por parte das Nações Unidas, visando não apenas a manutenção da ordem (que relacionamos ao binômio "paz e segurança"), mas o controle do ritmo, da profundidade e do teor das mudanças estruturais (que podemos relacionar à idéia de justiça).

O idealismo dos fundadores da ONU desdobrava-se em duas vertentes de implantação da nova ordem jurídica internacional: (i) um sistema de manutenção da paz e da segurança internacionais, visando "preservar as gerações vindouras do flagelo da guerra"; e (ii) o desenvolvimento de interdependências produtivas entre todos os Estados nos mais variados campos das relações internacionais.

A conservação da estrutura requer, no entanto, o estabelecimento de um conjunto aceitável de regras comuns, capazes de servir como linhas-mestras para a conduta de cada membro e também para a atuação dos órgãos intergovernamentais das Nações Unidas. Essas linhas-mestras podem ser encontradas nos dois primeiros artigos da Carta da ONU, sob o auspicioso título de "Propósitos e Princípios", verdadeiros fundamentos das Nações Unidas. ${ }^{3}$

\section{Propósitos e princípios - funções e obrigações}

Os propósitos - ou seja, as funções, as finalidades às quais as Nações Unidas almejam atender - referentes ao tema da manutenção da paz e da segurança internacionais estão postos em seu art. 1 (1), onde se lê que é propósito das Nações Unidas:

To maintain international peace and security, and to that end: to take effective measures for the prevention and removal

\footnotetext{
3 Ainda que as raízes de tais fundamentos possam ser traçadas até o Pacto da Sociedade das Nações, até o pensamento de Imannuel Kant ou mesmo até as origens da civilização judaico-cristã ocidental, é apenas a partir da Carta das Nações Unidas que a sociedade internacional efetivamente tenta se transformar em uma comunidade internacional, adotando mecanismos mais claros e mais efetivos para conduzir essa transformação. Um dos campos mais relevantes nessa travessia é aquele que enfrenta o clássico problema do Direito Internacional clássico e que a partir da experiência da Sociedade das Nações a comunidade internacional ambiciona transformar: a questão da guerra e da paz, traduzida no imperativo de manutenção da paz e da segurança internacionais e de proibição do uso da força em geral. A análise dos propósitos e dos princípios que se segue, portanto, é orientada por esse corte metodológico.
} 
of threats to peace, and for the suppression of acts of aggression or other breaches of the peace, and to bring about by peaceful means, and in conformity with the principles of justice and international law, adjustment or settlement of international disputes or situations which might lead to a breach of the peace.

A redação do art. 1 (1) é pouco técnica, possibilitando uma série de interpretações contraditórias quanto às peculiaridades de suas effective measures, todavia a finalidade é bem clara: manter a paz e a segurança nas relações entre os Estados. Tal finalidade, como aponta Alf Ross, é a essência da Carta das Nações Unidas, o ponto no qual ela revoluciona as regras de Direito Internacional até então vigentes. As controvérsias internacionais passam a ser consideradas um assunto público, caro a toda a comunidade internacional, positivando finalmente a paz como algo indivisível. Antes da Carta da ONU, as decisões que impunham sanções a Estados que desobedecessem as regras da paz eram facultadas aos demais Estados. A partir da Carta da ONU, uma sanção é realmente uma sanção e como tal deve ser cumprida ou respeitada por todos os Estados, incorrendo em atos ilícitos todos aqueles que a violarem. ${ }^{4}$

O sistema de manutenção da paz e da segurança internacionais conforme construído pela Carta da ONU é alicerçado sobre cinco pilares: (i) a proibição do uso arbitrário da força em geral contra outro Estado; (ii) o sistema de segurança coletiva para disciplinar a legitimidade do uso da força contra um Estado transgressor; (iii) o sistema de solução pacífica das controvérsias internacionais, destinado a esvaziar a necessidade do uso da força; (iv) as regras de controle e redução de armamentos, para redução tanto quanto possível da capacidade destrutiva dos Estados; (v) as incipientes regras de mudança pacífica, destinadas a assegurar a já mencionada conservação responsável da ordem internacional, evitando o colapso do sistema. ${ }^{5}$

Os princípios da Carta das Nações Unidas estão consolidados no art. 2, apresentando uma seqüência mais ou menos lógica. É importante ter em mente, ao tomar conhecimento de seu conteúdo, que estes princípios constituem obrigações de conduta, necessárias para consecução das funções, ou propósitos, da Carta. Assim, o art. 2 (3) é uma obrigação de solução pacífica das controvérsias internacionais: "all Members shall settle their international disputes by peaceful means in such a manner that international peace and security, and justice, are not endangered".

4 ROSS, A. United Nations - Peace and Progress. Nova Jersey: Bedminster, 1966.

5 Essa sistematização se encontra nos comentários sobre o art. 2 (4) de RANDELZHOFER, A. In: SIMMA, B. (Ed.). The Charter of the United Nations - a commentary. New York: Oxford University Press, 1995. p. 109. 
Uma reflexão lógica é necessária nesse ponto: por que os Estados devem solucionar suas controvérsias sem recorrer ao uso da força? O Direito Internacional Público clássico orienta-se a partir de um postulado jurídico quanto à natureza de seus sujeitos: todos os Estados são igualmente soberanos. No campo dos valores, consagra-se como valor maior a paz, entendida em sentido amplo como o respeito às soberanias de cada Estado. O mundo dos fatos, por sua vez, apresenta uma profunda assimetria entre os Estados, no que tange a fatores políticos, econômicos e mesmo ideológicos, cada um atuando no sentido de se fortalecer comparativamente aos demais, de modo a garantir o respeito à sua soberania. A igualdade soberana é consagrada pelo art. 2 (1) da Carta das Nações Unidas.

Efeito direto da igualdade soberana é a necessidade de se organizar o uso da força, uma vez que todos os Estados gozam dos mesmos direitos e das mesmas obrigações, embora tenham potências diferentes, estando suscetíveis ao perecimento no choque de forças com outros Estados. Ora, o uso da força é regulamentado pela Carta da ONU à luz do valor paz enquanto respeito à soberania, sendo proibido em geral e permitido em situações específicas. O art. 2 (4) da Carta é a regra jurídica para essa obrigação.

Se o uso da força é proibido em geral, não podendo nenhum Estado impor as suas vontades sobre um vizinho, exceto quando autorizado de acordo com as regras da própria Carta da ONU, então os Estados precisam de uma alternativa não-violenta para resolver suas desavenças. Mais uma vez, tendo em vista a igualdade soberana, que torna as vontades dos Estados equivalentes e dignas da mesma consideração, e tendo em vista o valor paz enquanto mútua abstenção, os Estados necessitam de uma solução que respeite a paz e permita solucionar o problema. Essa solução é o exame racional do problema a partir de algum critério.

Qual critério? A obrigação de resolver pacificamente as controvérsias é uma “obrigação jurídica de resolver", e não uma "obrigação de resolver juridicamente". Ou seja, é um dever de resolver, e não um dever de aplicar o Direito. Assim, a solução a partir do Direito é apenas uma das vias possíveis. A outra via é a solução a partir da satisfação política dos interesses. Nesse sentido, o Direito Internacional se permite evoluir tendo em vista não apenas as regras do Direito, mas também as oportunidades da Política, concorrendo ambos no esforço de construir a justiça e a paz. ${ }^{6}$

\footnotetext{
6 Comparar com o raciocínio sistêmico desenvolvido por C. Tomuschat sobre o art. 2 (3) SIMMA, B. (ed.) The Charter of the United Nations - a commentary. New York: Oxford University Press, 1995. p. 99.
} 
Muitos são os problemas de consistência diagnosticados na Carta da ONU, o que se explica por seu processo de elaboração. A primeira versão foi obra de um grupo de burocratas americanos liderados pelo Secretário de Estado dos Estados Unidos da América, Cordell Hull. O projeto de Hull foi extensamente revisado e negociado entre Estados Unidos, União Soviética, Reino Unido e China, sendo o produto dessa revisão das potências rediscutido por quatro dúzias de governos em San Francisco, 1945. Não se pode falar em uma voluntas legislatori para interpretar a Carta das Nações Unidas porque a vontade do legislador está demasiado diluída em mútuas concessões políticas e a voluntas legis oferece tais inconsistências que tornam a interpretação, seja ela autêntica ou doutrinária, tarefa ingrata e demasiado suscetível às concepções políticas. Com efeito, a grande maioria dos "nós" terminológicos amarrados pelos autores da Carta foi desatada politicamente, como veremos ao longo deste trabalho.

Ao contrapor o art. 1 (1) e o art. 2 (3), como já observava Kelsen, temos a primeira inconsistência da Carta: as previsões referentes às funções da Organização diferem das obrigações a que estão submetidos os membros. ${ }^{7}$ Como vimos, as obrigações de conduta dos membros expostas nos parágrafos do art. 2 estão relacionadas à finalidade exposta no art. 1 (1). Mas, enquanto o art. 1 (1) menciona "adjustment or settlement of international disputes or situations", o art. 2 obriga os membros a "settle their international disputes". Além disso, o art. 1 (1) exige que as controvérsias e situações sejam resolvidas por meios pacíficos em conformidade com a justiça e com o Direito Internacional, enquanto o art. 2 obriga os Estados a empregarem meios pacíficos que não ameacem a paz e a segurança internacionais, ou a justiça. ${ }^{8}$

O motivo pelo qual os membros estão obrigados a solucionar controvérsias, mas não se encontram obrigados a solucionar situações é simples. A consagrada definição

\footnotetext{
KELSEN, H. The Law of the United Nations. Londres: Stevens, 1950. p. 359.

8 Para efeitos deste artigo, utilizaremos conceitos de controvérsia e situação a partir das contribuições de Hans Kelsen e Charles de Visscher à definição originalmente proposta pela Corte Permanente de Justiça Internacional no julgamento do Caso das Concessões Mavrommatis na Palestina (1924). Confrontadas as definições de Kelsen e de Visscher, face à da antiga Corte, podemos destacar os elementos essenciais de uma controvérsia internacional, formulando uma definição mais adequada para o conceito: uma controvérsia internacional é um conflito racional de teses oponíveis entre dois (ou mais) sujeitos de Direito Internacional sobre suas respectivas obrigações perante um determinado objeto. Em outras palavras, uma controvérsia internacional ocorre quando dois sujeitos interpretam de modo diferenciado suas obrigações internacionais perante um certo objeto limitado e claramente definido, surgindo dessa divergência de interpretação pretensões distintas de conduta. Vide: CPJI. Publications de la Cour. Série A, n. 02, p. 11. KELSEN, H. Théorie du Droit International Public. Recueil des Cours, v. 84, 1953. VISSCHER, C. de. Theories et realités en droit international public. Paris: Pedone, 1970. p. 371.
} 
de controvérsia exarada pela CPJI, em 1924, aponta que controvérsia é um desacordo de fato ou de direito no qual os interesses de cada uma das partes estão suficientemente bemestruturados a ponto de serem analisados racionalmente dentro do Direito Internacional positivo. Ora, controvérsia é o termo forte e situação é o termo fraco, definido como tudo aquilo que opõe dois ou mais Estados, mas prescinde de um intangível elemento de racionalidade que possibilitaria seu exame à luz do Direito Positivo. Pode haver na essência da questão interestatal um antagonismo fundamental, insanável dentro do Direito Positivo (e talvez justamente por causa do Direito Positivo), o que exige a criação de direito novo.

Assim, se decorre da própria definição de situação a dificuldade estrutural de se a resolver racionalmente, não há sentido em obrigar os Membros a resolvê-las pacificamente, porque os Membros são incapazes de compreender a situação como algo que o Direito seja capaz de solucionar. Não-obstante, as situações podem produzir diversas controvérsias que, a despeito de serem resolvidas pacificamente, tendem a acirrar o ânimo das partes em relação à situação. Obrigar os membros a resolver suas situações por meios pacíficos dentro do Direito Internacional positivo é criar uma obrigação inexecutável. Sabiamente, os autores retiraram essa obrigação dos Membros, mas não as retiraram das obrigações da Organização, as quais coletivamente disporiam das condições - entre as quais destacamos o distanciamento - para constatar as situações e proceder ex officio para resolver a situação e prevenir controvérsias ou violações da paz.

A questão das expressões "ajuste" e "solução" é, no entender de boa parte dos doutrinadores, uma diferenciação semântica que não está perfeitamente explicada pela letra da Carta. Entre as possibilidades delineadas, estão a de que os termos são sinônimos, mas se aplicam a situações diferentes. Mas “adjustment” e "solution”, na língua inglesa, são tratados como termos sinonímicos no que tange à solução de uma situação problemática, aqui entendida no sentido menos técnico possível. Outra possibilidade de interpretação consiste em diferenciar ajustes e soluções quanto ao objeto. Os ajustes seriam aplicáveis às situações e as soluções seriam aplicadas às controvérsias. Essa interpretação está de acordo com o art. 2 (3). Se os Membros estão obrigados a solucionar as suas controvérsias, está claro que o 'ajuste' de controvérsias não é obrigatório. A solução de controvérsia dá um caráter de finalidade indiscutível, já que a solução extingue a controvérsia. Ajustar uma controvérsia, portanto, é algo menor que solucionar uma controvérsia. Assim, a idéia de ajuste recai apenas sobre as situações, as quais resultam insolúveis pelo Direito Internacional positivo, mas podem ser perfeitamente administradas com a adoção de medidas provisórias, que possam viabilizar uma eventual solução posterior. 
A terceira e última diferenciação recai sobre os destinatários da norma. $\mathrm{O}$ art. 1 (1) configura uma finalidade das Nações Unidas enquanto organização internacional dispondo de órgãos para cumprimento de seus propósitos. O art. 2 (3) configura uma obrigação para cada um dos Membros, cuja conduta deve ser individualmente correta no âmbito desse artigo. Assim, a ONU está obrigada a agir conforme os princípios da justiça e as regras do Direito Internacional. Os Membros, por sua vez, estão obrigados exercer sua soberania, de modo que as suas atitudes não ameacem a paz e a segurança internacionais, e a justiça. A ação da ONU deve se pautar pela estrita legalidade. E essa legalidade só poderá ser descumprida em favor de critérios transcendentais de defesa da justiça. Por outro lado, os Membros estão obrigados a resolver definitivamente as suas controvérsias, que por definição têm algum caráter jurídico, e podem, portanto, ser resolvidas dentro do Direito Internacional. Portanto, os Membros devem ter em mente que as suas decisões, que a própria Carta pressupõe corretas do ponto de vista formal, não poderão prejudicar a justiça, a segurança e a paz, três valores indissociáveis dentro da noção de relações internacionais que a Carta parece adotar. Ou seja, enquanto a ONU pode abrir mão da legalidade em benefício da justiça, transformando em jurídico o justo, os Membros não podem abrir mão da justiça, da segurança e da paz em benefício da legalidade, reduzindo o justo ao jurídico.

As exigências procedimentais decorrentes das funções e obrigações mencionadas se pretendem satisfeitas, no âmbito da própria Carta pelas disposições do Capítulo VI e complementadas pelas disposições relacionadas aos main bodies relacionados ao tema, Conselho de Segurança, Assembléia Geral, Secretariado e Corte Internacional de Justiça, além do papel reservado aos acordos regionais. São estes os elementos que compõem o sistema de solução pacífica de controvérsias das Nações Unidas, devendo concorrer para a correta aplicação não apenas do princípio da solução pacífica, mas também para a correta aplicação de todas as demais obrigações relacionadas à matéria.

Não-obstante esta série de inconsistências, o princípio da solução pacífica de controvérsias tem sido reafirmado em resoluções da Assembléia Geral, inclusive a Res. n. 2.627 (XXV), de 24 de outubro de 1970, a Res. n. 2.734 (XXV), de 16 de dezembro de 1970 e a Res. n. 40/9, de 8 de novembro de 1985. Ademais, o tema é tratado na "Declaration on Principles of International Law concerning Friendly Relations and Cooperation among States in accordance with the Charter of the United Nations" ("Declaração de Relações Amistosas", anexa à Res. n. 2.625 (XXV), de 24 de outubro de 1970), na "Manila Declaration on the Peaceful Settlement of International Disputes" ("Declaração de Manila", anexa à Res. n. 37/10, de 15 de novembro de 1982), na "Declaration on the 
Prevention and Removal of Disputes and Situations Which May Threaten International Peace and Security and on the Role of the United Nations in This Field" ("Declaração de 1988”, anexa à Res. n. 43/51, de 5 de dezembro de 1988), e na "Declaration on Factfinding by the United Nations in the Field of the Maintenance of International Peace and Security" ("Declaração sobre Poderes Investigatórios", anexa à Res. n. 46/59, de 9 de dezembro de 1991).

Nas Resoluções da Assembléia Geral, o princípio é constantemente reafirmado, havendo quase sempre um "solemn appeal" para a observância desse princípio. São atos políticos que pouco contribuíram para o desenvolvimento da matéria, mas que demonstram a importância política conferida ao tema. A Declaração de Relações Amistosas reconhece a proeminência do princípio da solução pacífica de controvérsias internacionais, e busca especificar sua abrangência e seu conteúdo, não indo muito além do conteúdo da própria Carta. A Declaração de Manila, apesar de muito mais detalhada, igualmente pouco inova em relação ao texto da Carta: elenca uma série de deveres dos Estados e reafirma uma série de competências de órgãos das Nações Unidas. A Declaração de 1988 é, sem dúvida, a mais inovadora, uma vez que trata com maior profundidade da importância fundamental da prevenção de controvérsias. Diz a cláusula primeira desta Declaração, de modo bastante direto e incisivo, que os Estados "should act so as to prevent in their international relations the emergence or aggravation of disputes or situations, in particular by fulfilling in good faith their obligations under international law”. A obrigação esboçada na Carta dizia respeito à solução de controvérsias já existentes; ao incluir a idéia de prevenção associada ao exercício de boa-fé de suas obrigações internacionais, a Declaração de 1988 introduz uma vertente ética à idéia de solução pacífica de controvérsias.

\section{Solução pacífica de controvérsias - capítulo VI}

O Capítulo VI da Carta, intitulado "Pacific Settlement of Disputes” lida, principalmente, com os poderes de que dispõe o Conselho de Segurança para efetivamente aplicar o princípio da solução pacífica. Evidentemente, a mera consagração do princípio na forma de uma obrigação não seria suficiente para estabelecer uma ordem internacional pacífica e harmoniosa. A idéia de se disciplinar o campo da solução de controvérsias, estabelecendo órgãos multilaterais com competência para assegurar a manutenção da paz e da segurança internacionais complementa a obrigação no sentido de garantir que não 
recairá apenas sobre os envolvidos a responsabilidade pela manutenção da paz e pela eliminação do risco de guerra.

É por isso que a Carta da ONU confere ao Conselho de Segurança a responsabilidade principal pela manutenção da paz e da segurança internacionais. As decisões do Conselho de Segurança sob a égide deste Capítulo tendem a não possuir força vinculante, o que, aliás, fica demonstrado pela extensa utilização do termo "recommends" ao longo do capítulo, mas o impacto moral de se insurgir contra uma resolução aprovada pelos membros do Conselho nem sempre é politicamente viável para a estrutura política do Estado.

O art. 33 (1) retoma o princípio da solução pacífica nos seguintes termos:

The parties to any dispute, the continuance of which is likely to endanger the maintenance of international peace and security, shall, first of all, seek a solution by negotiation, enquiry, mediation, conciliation, arbitration, judicial settlement, resort to regional agencies or arrangements, or other peaceful means of their own choice.

Como havíamos visto, o art. 2 (3) fala em "all disputes”, enquanto o art. 33 (1) fala em "disputes the continuance of which is likely to endanger the maintenance of international peace and security". Aparentemente, a Carta pretende que apenas as controvérsias que ameacem a paz e a segurança internacionais sejam trazidas ao conhecimento da ONU. Uma explicação possível pode ser obtida a partir da utilização do termo "first of all". Todas as controvérsias devem ser resolvidas pelas partes, que a isto estão obrigadas pelo art. 2 (3). Já as controvérsias que ameaçam a paz e a segurança internacionais criam uma obrigação não apenas para as partes, mas também para terceiros e para a comunidade internacional organizada na forma de Nações Unidas, tendo em vista que o art. 1 (1) diz que a função das Nações Unidas é solucionar controvérsias e outras situações que possam romper a paz ("may lead to a breach of the peace"). Em respeito à igualdade soberana, roga-se às partes resolverem first of all por meios pacíficos, cabendo às Nações Unidas acompanhar a questão, respeitando a soberania das partes na medida em que estas respeitarem os princípios das Nações Unidas, recorrendo a quantos meios pacíficos forem necessários para resolver a controvérsia. Daí surge outra questão: há necessidade de esgotamento dos meios pacíficos para que as Nações Unidas possam interferir em uma controvérsia? O próprio Conselho de Segurança deliberou sobre o 
assunto, nos primeiros anos de suas atividades, considerando desnecessário o esgotamento de todos os meios. ${ }^{9}$

Um segundo princípio referente à matéria da solução de controvérsias trata do respeito à liberdade de opção de que os Estados gozam dentre os diversos mecanismos. Uma vez que os Estados estão, cada vez mais, obrigados a resolver dentro das hipóteses pacíficas as suas divergências, o princípio da igualdade soberana fez resguardar a liberdade e a autonomia dos Estados para escolher os mecanismos de sua preferência. $\mathrm{O}$ art. 33 da Carta das Nações Unidas enumera uma lista não-limitante de procedimentos de solução pacífica que possam ser utilizados pelos Estados: negociação, mediação, inquérito, conciliação, arbitragem, solução judicial, recurso a agências regionais, ou outros.

Dentro da variedade de mecanismos disponíveis, os Estados podem estar obrigados a recorrer a determinados mecanismos. Isso se dá quando o Estado se compromete antecipadamente, por via de tratados internacionais, a se submeterem a um procedimento determinado. Quando não existe um comprometimento prévio de solução pacífica por meio determinado, é cada vez mais comum a participação de organizações internacionais. O desenvolvimento desses órgãos, notadamente a partir de 1945, estimula os Estados litigantes a confiarem suas controvérsias aos mecanismos de solução incluídos no seio das organizações internacionais.

Desnecessário afirmar que a liberdade de escolha faculta aos Estados as mais discricionárias combinações de mecanismos e procedimentos de solução de controvérsia. Não há qualquer hierarquia ou ordem entre as diversas opções existentes, podendo até mesmo ocorrerem simultaneamente várias frentes de solução. $\mathrm{O}$ único critério verdadeiramente objetivo é a estratégia individual de cada Estado no esforço de assegurar seus interesses.

Disso decorre outro problema: nem todos os meios disponíveis são igualmente eficazes e nem todo Estado está verdadeiramente interessado em resolver a controvérsia de modo justo e eficaz. Por causa disso, há uma tendência mundial de impor critérios sistemáticos aos diversos procedimentos, bem como organizar doutrinariamente os mecanismos de acordo com a natureza do conflito. Os tratados internacionais têm refletido esses esforços, mas a prática nem sempre correspondeu ao delineado na teoria. Mais de uma comissão de conciliação, por exemplo, já atuou como órgão de arbitragem, e vários processos de inquérito concluíram-se com propostas de resolução, ultrapassando assim os seus limites.

9 Não-obstante, em 1973, os Estados Unidos barraram a adoção de uma resolução sobre o Canal do Panamá alegando que as partes ainda não haviam esgotado todos os meios. 


\subsection{A Corte Internacional de Justiça}

A Carta das Nações Unidas estabelece um mecanismo opcional de solução judiciária das controvérsias, o qual, na perspectiva mais otimista, se tornaria o único necessário: a Corte Internacional de Justiça (CIJ).

A CIJ exerce competências consultivas e contenciosas. Exercendo sua competência consultiva, a CIJ emite pareceres sobre temas variados do Direito Internacional a pedido dos Estados, da Assembléia Geral ou do Conselho de Segurança. Também podem requerer pareceres consultivos à CIJ algumas agências especializadas da ONU, autorizadas pela Assembléia Geral. A competência contenciosa é exercida no julgamento de controvérsias surgidas entre Estados soberanos mediante a aplicação do Direito Internacional. A jurisdição da Corte é facultativa em respeito ao princípio da livreescolha de meios. ${ }^{10}$

A decisão da Corte, a princípio, é obrigatória sem ser executória. Em circunstâncias especiais, porém, as decisões podem se tornar executórias. Tal possibilidade está prevista no art. 94 da Carta das Nações Unidas:

If any party to a case fails to perform the obligations incumbent upon it under a judgment rendered by the Court, the other party may have recourse to the Security Council, which may, if it deems necessary, make recommendations or decide upon measures to be taken to give to the judgment.

\subsection{O Conselho de Segurança}

O art. 94 evidencia a primazia conferida ao Conselho de Segurança, como verdadeiro fiador da paz internacional, consagrando a idéia do concerto necessário das

\footnotetext{
${ }^{10}$ Durante as negociações da primeira versão da CIJ, ainda em 1919, não havia consenso quanto à obrigatoriedade de sua jurisdição, motivo pelo qual a delegação brasileira saiu-se com a proposta da "cláusula facultativa de jurisdição obrigatória", positivada pelo art. 36 (2) do Estatuto da Corte. Controvérsias entre Estados signatários dessa cláusula podem ser encaminhadas automaticamente à Corte por qualquer das partes, sem a necessidade de se estabelecer um compromisso. Cerca de sessenta países encontram-se atualmente vinculados a esta cláusula. Entre os países mais expressivos do globo terrestre, China, Estados Unidos e Rússia optaram por não-admitir a jurisdição obrigatória. O Brasil, propositor da cláusula, esteve vinculado, mas retirou-se, recuperando a velha tradição de apoio aos procedimentos não-jurisdicionais. Uma eventual adesão maciça à cláusula facultativa de jurisdição obrigatória tornaria desnecessários os demais meios pacíficos, tão logo a Corte dispusesse de juízes suficientes.
} 
potências como pré-requisito da paz internacional. O art. 24 (1) da Carta assinala a responsabilidade principal conferida ao Conselho de Segurança na manutenção da paz. ${ }^{11}$

O caráter optativo da jurisdição da CIJ - reflexo do princípio de livre escolha dos meios de solução - faz com que não exista um órgão específico para solução de controvérsias, ao contrário do que ocorre, por exemplo, na Organização Mundial do Comércio. A responsabilidade conferida ao Conselho de Segurança tem um caráter muito mais político do que propriamente jurídico. Se, por um lado, o Conselho de Segurança centraliza razoavelmente a atividade sem utilizar-se necessariamente do Direito posto, por outro mantém-se sempre facultado às partes o recurso a qualquer outro procedimento de sua preferência e o direito de não aceitar a recomendação do Conselho.

Falar de um sistema de solução de controvérsias das Nações Unidas é, portanto, falar de toda uma série de opções procedimentais disponibilizadas aos Estados quando os recursos bilaterais ou regionais forem incapazes de solucionar a pendência. Nestes momentos, cumpre inicialmente ao Conselho de Segurança aplicar o Capítulo VI e assegurar a manutenção da paz e da segurança internacionais.

Inicialmente, o Conselho de Segurança foi concebido para funcionar como o órgão restrito da $\mathrm{ONU}$, no qual se procuraria recuperar a prática do concerto entre as grandes potências, à moda do Concerto Europeu. O tema da composição do órgão é, desde 1945, o mais problemático, demonstrando que as reais preocupações dos governos dos Estados passam longe da efetiva manutenção da paz e da segurança internacionais, ou melhor, que a representatividade internacional condiciona o grau de adesão às regras internacionais. $^{12}$

$\mathrm{O}$ art. 24 (1) da Carta estabelece que os Membros conferem ao Conselho "the primary responsibility for the maintenance of international peace and security". Esta responsabilidade é limitada pelo art. 24 (2), o qual condiciona a ação do Conselho aos propósitos e princípios da Carta. Tal ação é realizada em nome de todos os membros das

\footnotetext{
11 Apenas em duas oportunidades a parte vencida em uma controvérsia submetida à Corte recusou-se a cumprir a sentença: o Caso do Estreito de Corfu (Reino Unido v.s. Albânia, 1947), posteriormente desenvolvido no Caso do Ouro Monetário de Roma (Estados Unidos, França e Reino Unido v.s. Itália, 1953); e o Caso das Atividades Paramilitares na Nicarágua (Nicarágua v.s. Estados Unidos), no qual os Estados Unidos não reconheceram a sentença, mas aprovaram um plano de auxílio à Nicarágua, implementado após a queda dos sandinistas, que supria razoavelmente os valores indenizatórios estabelecidos pela CIJ.

12 Compõe-se o Conselho de Segurança de: cinco membros permanentes, dos quais se exige convergência de votos para adoção de resolução em matérias substantivas, e dez membros não-permanentes eleitos pela Assembléia Geral em vista das contribuições individuais no campo da manutenção da paz e a representação geográfica de quinze membros. Essa composição só pode ser alterada por emendas à Carta das Nações Unidas, que exige maioria de dois terços na Assembléia Geral, incluindo os votos favoráveis dos cinco membros permanentes, o que torna virtualmente impossível qualquer reforma que altere o número de membros permanentes.
} 
Nações Unidas, manifestando, portanto, a vontade da comunidade internacional. Este é o dever principal que a Carta dá ao Conselho. Mas a competência e as responsabilidades do Conselho são ainda mais amplas e complexas. O art. 24 (2) observa que as atribuições específicas do Conselho de Segurança para o cumprimento desses deveres estão enumeradas nos Capítulos VI, VII, VIII e XII.

Para cumprir seu dever de manutenção da paz e da segurança internacionais, a Carta confere poderes especiais ao Conselho, conferidos sob diversos capítulos da Carta, principalmente os Capítulos VI e VII. O Capítulo VI trata de solução pacífica, e o Capítulo VII regula as medidas coercitivas que o Conselho pode utilizar. Às decisões tomadas no âmbito do Capítulo VI, atribui-se caráter não-vinculante; às decisões tomadas no âmbito do Capítulo VII, atribui-se caráter vinculante. A diferenciação surge da própria redação da Carta: o Capítulo VI usa constantemente o verbo reccomends, enquanto o Capítulo VII estabelece menções claras à obrigatoriedade de suas decisões (decides) para todos os Membros das Nações Unidas. Isso torna o Capítulo VI relativamente fraco em relação ao Capítulo VII, sentindo-se os Estados livres para ignorar as decisões tomadas no âmbito do Capítulo VI. Por conta disso, o próprio Conselho estabeleceu um modo de resguardar suas resoluções. Decisões e recomendações evitam mencionar os artigos da Carta em que se baseiam e utilizam a linguagem mais suave e vaga possível. ${ }^{13}$

\subsubsection{Interpelação e incorporação do assunto à agenda}

Qualquer manifestação que o Conselho de Segurança emita acerca de uma controvérsia, seja no âmbito do Capitulo VI, seja no âmbito de qualquer outro dispositivo da Carta, dependerá evidentemente da ativação de seus poderes. O procedimento pelo qual o Conselho de Segurança é notificado da existência de uma controvérsia é regulado principalmente pelo art. 35 da Carta das Nações Unidas. De acordo com este artigo, o Conselho pode ser notificado por qualquer Membro da ONU, por um Estado não-membro que seja parte em uma controvérsia, pela Assembléia Geral ou pelo Secretário-Geral. ${ }^{14}$

\footnotetext{
13 A prática da não-dissociação de poderes do Conselho de Segurança é de extrema importância, uma vez que disposições que servem principalmente ao tema da segurança coletiva podem ser aplicadas para solução de controvérsias, com aparente vinculação obrigatória. O contratempo dessa prática é a dificuldade em se fazer com que se produza consenso entre os membros permanentes quanto aos termos em que o Conselho se dirige aos Estados.

${ }^{14}$ A idéia de que qualquer Membro da ONU possa trazer à atenção do Conselho qualquer controvérsia, ou qualquer situação que possa conduzir a uma, tem por base a idéia de que a paz é indivisível. Qualquer ameaça à relação pacífica entre dois Estados significa também uma ameaça à estabilidade de toda a Comunidade Internacional. Assim, a idéia de que todo o Membro da organização tem o direito de solicitar ao Conselho de Segurança providências para a solução de uma controvérsia faz deste dispositivo, a actio popularis do direito
} 
Aos membros da ONU, confere o art. 35 (1) a seguinte faculdade:

Any Member of the United Nations may bring any dispute, or any situation of the nature referred to in Article 34 [which might lead to international friction or give rise to a dispute], to the attention of the Security Council or of the General Assembly.

Ademais, o art. 37 (1) estabelece a seguinte obrigação:

Should the parties to a dispute of the nature referred to in Article 33 ["which is likely to endanger the maintenance of international peace and security"] fail to settle it by the [peaceful] means indicated in that Article, they shall refer it to the Security Council.

Como não poderia deixar de ser, já que nos referimos ao Capítulo VI da Carta, a redação do art. 35 (1) é problemática. A expressão “any Member” inclui as partes da controvérsia ou situação, podendo estas recorrer tanto ao Conselho de Segurança quanto à Assembléia Geral, conforme julgarem politicamente mais sensato. Ora, de acordo com o art. 33 (1), as Partes devem buscar a solução pacífica das controvérsias em entendimento bilateral antes de recorrer às Nações Unidas, devendo recorrer diretamente ao Conselho de Segurança (e não à Assembléia Geral), nos termos do art. 37 (1), quando os entendimentos bilaterais tiverem fracassado.

$\mathrm{O}$ sentido de ambas as regras é exatamente o mesmo: permitir à ONU, por iniciativa de seus Estados-Membros, manifestar-se acerca de uma dada controvérsia internacional. A distinção que merece ser feita quanto ao art. 35 (1), na verdade, é o fato de que tal regra permite a abertura de um procedimento ex officio do Conselho ou da Assembléia Geral, sem que as partes tenham sequer tentado resolver o conflito por meios pacíficos bilaterais. Tanto assim é que, como ao longo de todo o Capítulo VI, a prática ignora as possíveis distinções, não importando se o Conselho age por força do art. 35 (1) ou do art. 37 (1).

O Conselho pode ainda ser posto a par de uma controvérsia ou situação mediante requisição da Assembléia Geral ou do Secretariado. Nos termos do art. 11 (3): "the General Assembly may call the attention of the Security Council to situations which are likely to endanger international peace and security”. As situações a que se refere o art. 11 (3) ( "situations which are likely to endanger international peace and security") devem ser interpretadas como incluindo a idéia de controvérsia entre as situações possíveis.

internacional. COT, J.-P.; PELLET, A. Le Charte des Nations Unies: Commentaire article par article. Paris: Economica, 1991. p. 588. 
Assim, a Assembléia Geral está autorizada a interpelar o Conselho quanto a qualquer controvérsia ou outra situação que lhe pareça danosa à manutenção da paz e da segurança internacional. ${ }^{15}$ Nas hipóteses de uso da força, conforme mencionada no art. 11 (2), a Assembléia Geral está obrigada a reportar o assunto à discricionariedade do Conselho de Segurança.

O direito de interpelação é também a única atribuição explícita conferida ao Secretário-Geral referente ao tema da solução pacífica de controvérsias, e se encontra no art. 99 da Carta. De acordo com o texto do artigo, o Secretário-Geral poderá trazer ao conhecimento do Conselho de Segurança "any matter which in his opinion may threaten the maintenance of international peace and security". ${ }^{16}$

Devidamente informado, o Conselho de Segurança, por meio de seu presidente, promoverá os atos destinados a assegurar a discussão do assunto pelo Conselho. Dá conta disto a Regra de Procedimento n. 03 do Procedimento do Conselho de Segurança:

\begin{abstract}
The President shall call a meeting of the Security Council if a dispute or situation is brought to the attention of the Security Council under Article 35 or under Article 11 (3) of the Charter, or if the General Assembly makes recommendations or refers any question to the Security Council under Article 11 (2), or if the Secretary-General brings to the attention of the Security Council any matter under Article 99.
\end{abstract}

\footnotetext{
15 As situações a que se refere o art. 11 (3) devem ser interpretadas como incluindo a idéia de controvérsia entre as situações possíveis. Assim, a Assembléia Geral está autorizada a interpelar o Conselho quanto a qualquer controvérsia ou outra situação que lhe pareça danosa à manutenção da paz e da segurança internacionais.

${ }^{16}$ O Secretário-Geral goza de muito prestígio entre os governantes e entre os diplomatas de todo o mundo, pivô funcional da organização que a representa e simboliza na luta pela observação de seus princípios e consecução de suas finalidades. Não-obstante, durante o período em que existiu, a União Soviética protestou largamente contra o exercício do poder de interpelação por parte do Secretário-Geral, geralmente visto pelo bloco socialista como contrário à igualdade soberana dos Estados. O primeiro Secretário-Geral, Trygve Lie (Noruega), utilizou-se do art. 99 por ocasião da crise da Coréia (1950), o que causou o voto contrário da União Soviética quando de sua recondução ao cargo. Dag Hammarskjöld (Suécia), seu sucessor, utilizou abundantemente a prerrogativa, com destaque para sua atuação na Crise do Congo (1960), em meio à qual perderia a vida. O terceiro ocupante do cargo, Sithu U Thant (Birmânia), não fez uso de suas prerrogativas no âmbito do art. 99 durante boa parte de seu mandato para não entrar em atrito com os soviéticos, mas acabou recorrendo à prerrogativa para solução do conflito em Bahrein. Kurt Waldheim (Áustria), o quarto SecretárioGeral, recorreu às competências implícitas do Secretário-Geral, atuando como mediador e oferecendo bons ofícios em algumas situações, entre as quais se destacam os seus esforços no início da Guerra Irã-Iraque (1980). Javier Pérez de Cuellar (Peru) fez uso igualmente implícito de sua prerrogativas, mas passou à agir com maior liberalidade quanto ao art. 99, conforme a Guerra Fria se distendeu. O fortalecimento da posição do Secretário-Geral no período pós-Guerra Fria durante os períodos de Boutros Boutros-Ghali e Kofi Annan tornou corriqueira, e até desejada, a atuação do Secretário-Geral nos esforços de paz, não necessariamente com base no art. 99 da Carta.
} 
O passo seguinte é incorporar o assunto à agenda pelo voto afirmativo de quaisquer nove membros. A mera adoção da agenda em um determinado assunto não significa nenhuma presunção de competência por parte do Conselho de Segurança. Qualquer tipo de manifestação quanto à competência do Conselho de Segurança deve, portanto, aguardar a entrada do assunto na pauta, não sendo, porém, permitido às partes retirar a matéria da agenda. Assim, mesmo que as partes tenham resolvido a controvérsia de acordo com o art. 33 (1), o Conselho ainda poderá permanecer ciente da questão, praticando, em sentido amplo, aquilo que Cassese denomina supervisão internacional. ${ }^{17} \mathrm{~A}$ controvérsia pode deixar de existir e ainda assim o Conselho tem poderes para continuar monitorando as partes, se assim lhe convenha. Isso permite ao Conselho evitar que as partes fraudem a sua jurisdição. ${ }^{18}$

A mera discussão de um assunto pelo Conselho já constitui por si só um evento político de grandes proporções, motivo pelo qual os países envolvidos em controvérsias ou situações envidam os melhores esforços para evitar que um assunto que lhes seja prejudicial entre na pauta de discussões do Conselho. Caso isso não seja possível e o assunto efetivamente entre na ordem do dia, o Conselho de Segurança procurará, nos termos dos arts. 31 e 32, fazer as partes e eventuais terceiros Estados interessados participarem da reunião. As partes estão automaticamente convidadas a comparecer, e os terceiros interessados devem justificar sua presença demonstrando de que maneira os seus interesses podem se prejudicar pelas deliberações do Conselho de Segurança. Cumpre ao Conselho constatar a veracidade das afirmações dos terceiros interessados. Cada Estado convidado, parte ou apenas terceiro interessado, passa a constituir um membro "ad hoc" do Conselho de Segurança, ${ }^{19}$ podendo fazer uso da palavra, apresentar questões de ordem e discutir projetos de resolução. Preserva-se todavia apenas aos membros efetivos do Conselho o direito de propor a votação de um projeto de Resolução. Em síntese, os membros ad hoc do Conselho de Segurança gozam de todos os direitos de caráter procedimental, estando impedidos de participar em votações de ordem substancial.

Tendo sido convidadas as partes e tendo sido resolvida a presença dos terceiros interessados, a primeira reunião do Conselho de Segurança procurará dar espaço

\footnotetext{
${ }^{17}$ CASSESE, A. International Law in a Divided World. Oxford: Oxford University Press, 1986.

18 Em 1968, a Tchecoslováquia entrou em atritos com a União Soviética. O Conselho havia tomado conhecimento dessa situação e estava discutindo o assunto quando, poucos dias após a invasão da Tchecoslováquia pelo Exército Vermelho, o novo governo em Praga requereu a retirada do assunto da pauta do Conselho. O Conselho se recusou a atender a demanda tchecoslovaca, não-obstante protestos por parte da representação soviética, e uma resolução sobre a questão seria vetada pela União Soviética em agosto daquele ano.

19 KELSEN, H. op. cit. p. 410-16.
} 
para a apresentação dos fatos por ambas as Partes, além de manifestações acerca do tema pelos demais membros do Conselho, em um debate público. A ausência deliberada de uma das Partes não interrompe o procedimento e é vista, no mais das vezes, apenas como um ato descortês. A prática recente tem evitado debates públicos em assuntos demasiado delicados, optando-se pela prática de consultas privadas sob o patrocínio do presidente do Conselho de Segurança. Em outros casos, o Conselho pode optar por realizar reuniões secretas.

\subsubsection{Art. 34. Investigação}

Nem sempre a totalidade das informações trazidas pelos Estados permite ao Conselho de Segurança tomar qualquer atitude referente ao assunto, principalmente na questão tortuosa por meio da qual o Conselho define a situação que se lhe apresenta como uma controvérsia ou alguma outra situação, atestando-lhe o caráter nocivo à paz e segurança internacionais. Para preencher essa lacuna, os Aliados elaboraram o dispositivo que, sem grandes alterações, se transformaria no art. 34 da Carta das Nações Unidas. Diz o art. 34:

\begin{abstract}
the Security Council may investigate any dispute, or any situation which might lead to international friction or give rise to a dispute, in order to determine whether the continuance of the dispute or situation is likely to endanger the maintenance of international peace and security.
\end{abstract}

O art. 34 é a única menção explícita a uma competência investigatória por parte das Nações Unidas em todo o texto da Carta. Isso não quer dizer que apenas o Conselho possa conduzir investigações, tampouco que estas investigações devam se limitar à constatação da aplicabilidade do Capítulo VI da Carta. Existe, em verdade, uma competência geral de investigação, necessária para que os órgãos possam cumprir as funções que lhe foram atribuídas. Kelsen já constava a necessidade de se pressupor tal competência, ${ }^{20}$ e a Regra de Procedimento n. 39 aponta claramente neste sentido:

The Security Council may invite members of the Secretariat or other persons, whom it considers competent for the purpose, to supply it with information or to give other assistance in examining matters within its competence.

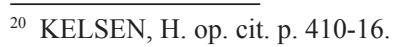


Aponta-se, porém, uma tendência a incumbir o Secretariado com a performance de investigações determinadas tanto pelo Conselho como pela Assembléia Geral.

Por meio do art. 34, o Conselho de Segurança pode investigar certas controvérsias e outras situações com um propósito específico. Consiste, portanto, a “decisão de investigar" em uma decisão procedimental destinada a esclarecer um dado assunto. O art. 29 faculta ao Conselho delegar a missão de investigação a órgãos especiais, subcomitês, comissões de investigação, ao Secretário-Geral ou a si mesmo, de acordo com a complexidade da questão e o ambiente político do momento da decisão. O objeto da investigação é bastante amplo: any dispute, or any situation which might lead to international friction or give rise to a dispute". Todavia, devemos considerar que uma situação que possa levar a uma fricção internacional ou dar ensejo a uma controvérsia só pode ser como tal classificada tão logo o Conselho disponha de informações suficientes sobre assunto. Assim, o art. 34 permite ao Conselho investigar qualquer situação, inclusive controvérsias. ${ }^{21}$ Em tese, portanto, a única limitação à aplicação do art. 34 acaba sendo o disposto no art. 2 (7). Todavia, nem mesmo a limitação do domínio reservado parece deter o Conselho de Segurança, uma vez que cabe ao próprio Conselho constatar, mediante investigação adequada, a violação da competência exclusiva dos Estados. ${ }^{22}$

Se, como vimos, a decisão de investigar é procedimental, a determinação da situação ou controvérsia como ameaçadora à paz e à segurança internacionais é indiscutivelmente substantiva, o que significa que deve contar com o consenso entre os cinco Membros permanentes. Além disso, tanto a decisão de investigar quanto a conclusão sobre a natureza da questão investigada é vinculante. Por isso, o órgão subsidiário que conduziu as investigações não pode determinar o resultado final das investigações. Deve apresentar seu relatório para que o Conselho, ou seja, pelo menos nove Membros, inclusive os permanentes, conclua tratar-se de uma controvérsia ou outra situação que ameace a paz e a segurança internacionais.

O grande problema da aplicação do art. 34 é o propósito específico da condução da investigação. Por conta desta limitação, o Conselho de Segurança tende a fazer uso do art. 24 juntamente com o art. 29 na eventualidade de precisar transcender

${ }^{21}$ SIMMA, B. (ed.) The Charter of the United Nations - a commentary. New York: Oxford University Press, 1995. p. 520.

${ }^{22}$ A Res. n. 163 (1961), referente à Questão Angolana, trata de uma questão de caráter colonial que adquire proporções de situação com caráter internacional por parecer ao Conselho que a continuação do conflito colonial português acabaria por colocar em perigo a paz e a segurança internacionais. SIMMA, B. op. cit. p. 506-7. 
tal limitação para o correto exercício das funções atribuídas pela Carta. Assim, menções ao art. 34, embora comuns em documentos encaminhados pelos Estados ao Conselho de Segurança, são raríssimas em resoluções do Conselho, que prefere utilizar a sua competência geral de investigação, a qual permite maiores aferições. Outras investigações conduzidas pelo Conselho de Segurança são muito mais numerosas e freqüentes, demonstrando a predileção do Conselho por conduzir inquéritos que não estejam constrangidos pelas limitações constantes do art. 34. A prática se consolidou no sentido de estabelecer comissões ou subcomitês com poderes investigatórios, de composição variada e competências específicas determinadas caso a caso. ${ }^{23}$

\subsubsection{Art. 33 (2). Recomendação geral de utilização dos meios pacíficos}

Uma vez constatada a materialidade dos fatos, o Conselho deve passar agora à discussão acerca da recomendação que poderá emitir às Partes. Entre as várias modalidades de intervenção do Conselho de Segurança para solução de uma controvérsia internacional, a mais branda está prevista no art. 33 (2) da Carta, o qual afirma que "the Security Council shall, when it deems necessary, call upon the parties to settle their dispute by such [peaceful] means [of their own choice]". Dizemos ser a intervenção mais branda por ser aquela que menos afeta a soberania dos Estados, uma vez que se limita a relembrar às Partes suas obrigações contraídas no âmbito do art. 2 (3) e, em verdade, limita-se a sublinhar aos Estados a responsabilidade principal pela solução do diferendo.

Isto não denota, todavia, qualquer tipo de omissão do Conselho de Segurança, uma vez que as resoluções do Conselho de Segurança nem sempre refletem toda a variedade de esforços e iniciativas de cunho político e diplomático que a envolveram. ${ }^{24}$ Uma resolução baseada no art. 33 (2) pode estar acompanhada de um intenso esforço de

\footnotetext{
${ }^{23}$ Menções específicas ao art. 34 podem ser encontradas apenas nas primeiras resoluções produzidas pelo Conselho de Segurança. A prática dá conta de apenas dois casos: a Resolução n. 15, de 19 de dezembro de 1946, sobre a Questão dos Incidentes Fronteiriços na Grécia; e a Resolução n. 39, de 20 de janeiro de 1948, sobre a Questão Indo-Paquistanesa. Em outras oportunidades, o Conselho utilizou parcialmente o fraseado do artigo sem mencioná-lo diretamente, como na Resolução n. 4, de 29 de abril de 1946, sobre a Questão Espanhola. Os repertórios da prática do Conselho de Segurança apontam os casos em que órgãos subsidiários foram empregados com fins investigatórios. Destacamos: o Caso do Canal de Corfu (1947), a Questão do Laos (1959), a Situação do Congo, por ocasião da morte de Patrice Lumumba (1961), os incidentes entre Camboja e Vietnã (1964), os incidentes fronteiriços na Guiné (1970 e 1971), a Situação no Senegal (1971), no caso da Zâmbia (1973), no Timor (1975), no Benin (1977), nos Territórios Árabes Ocupados (1979), nas Ilhas Seychelles (1981), no caso do conflito entre o Irã e o Iraque (1982) e no caso do conflito entre Angola e África do Sul (1985).

${ }^{24}$ SIMMA, B. op. cit. p. 506-7.
} 
negociação empreendido pelos Membros do Conselho de Segurança no sentido de evitar uma nova - e menos suave - intervenção.

O alcance de aplicação ratione personae deste artigo é bastante amplo. Enquanto o art. 33 (1) é dirigido principalmente aos Estados, os quais assumiram a obrigação de resolver pacificamente as suas controvérsias, o art. 33 (2) não pode limitar os poderes do Conselho de Segurança. As exortações feitas pelo Conselho de Segurança a facções em guerra dentro de um mesmo Estado, como as reiteradas resoluções referentes às guerras civis no Chipre e no Líbano durante os anos 70, demonstram a ampla abrangência do dispositivo.

O alcance ratione materiae é igualmente amplo: o Conselho se abstém de classificar as situações como "disputes" ou "other situations", preocupando-se exclusivamente em constatar a internacionalidade do conflito. Os apelos feitos com base no art. 33 (2) atestam a importância do princípio da subsidiariedade do Conselho em relação às Partes, sublinhando nas mais claras linhas a obrigação lhes cabe. A discricionariedade que a Carta fornece ao Conselho ("when it deems necessary") também previne o órgão de se manifestar em circunstâncias nas quais qualquer apelo seja inútil. ${ }^{25}$

\subsubsection{Arts. 36 a 38. Recomendações específicas para solução pacífica}

As recomendações específicas que o Conselho de Segurança pode fazer com vistas à solução pacífica de controvérsias estão contidas nos arts. 36, 37 e 38 da Carta. Os dispositivos dos três artigos foram discutidos conjuntamente e o resultado final foi muito mais um texto que incorpora um compromisso entre os diversos interesses e objetivos defendidos pelos Aliados do que propriamente um conceito jurídico preciso. ${ }^{26} \mathrm{O}$ motivo de tanto desencontro na redação dos três artigos origina-se de uma divergência entre os

\footnotetext{
25 Exemplo da aplicação do art. 33 (2) é a Resolução n. 27, de $1^{\text {o }}$ de agosto de 1946, sobre a Questão da Indonésia, na qual conclama as partes a resolverem suas controvérsias por arbitragem ou quaisquer outros meios pacíficos e manterem o Conselho de Segurança informado dos desdobramentos das negociações. Mais recentemente, uma resolução sobre o conflito entre África do Sul e Lesotho, a Resolução n. 527 (1982) de 15 de dezembro de 1982, faz um apelo solene à prática dos meios pacíficos para solução de controvérsias. Outros apelos, direcionados no sentido de estimular as negociações pelas Partes, foram emitidos por ocasião do conflito entre Irã e Iraque. Em duas outras oportunidades, o Conselho de Segurança se viu instado a solicitar às partes que aceitassem a solução por mediação, conciliação ou qualquer outra forma de solução pacífica das controvérsias. Durante a Guerra das Malvinas, o Conselho de Segurança solicitou às partes, através da Resolução n. 520 (1982), que encontrassem uma solução diplomática para o conflito. Durante a Guerra do Golfo, a Resolução n. 660 de 2 de agosto de 1990, determinou que os governos do Iraque e do Kuwait entrassem imediatamente em negociações para solução de suas diferenças.
}

${ }^{26}$ SIMMA, B. op. cit. p. 584 et seq. 
Estados Unidos e o Reino Unido quanto ao grau de ingerência do Conselho de Segurança em uma controvérsia, ainda durante a Conferência de Dumbarton Oaks. ${ }^{27}$

O trato do assunto durante a Conferência de San Francisco estabeleceu que o Conselho poderia fazer recomendações - ou seja, atos internacionais que não obrigam seus destinatários - sobre quais os melhores métodos de solução da controvérsia (ato de mediação) como quais os melhores termos de solução da mesma (ato de conciliação). Por fim, estabeleceu-se o mecanismo do art. 38, por meio do qual as partes submetem voluntariamente sua controvérsia ao Conselho de Segurança com vistas à sua solução pacífica, em um procedimento muito comparável à conciliação, embora se pressuponha que as partes estejam dispostas a aplicar a recomendação, motivo pelo qual espera-se que tenham recorrido ao Conselho nos termos do art. $38 .^{28}$

\section{Art. 36 (1). Bons Ofícios e Mediação}

A primeira modalidade de recomendação específica do Conselho de Segurança está contida no art. 36 da Carta das Nações Unidas. Num esforço de sistematização, buscando enquadrar a postura do Conselho de acordo com os tipos tradicionais de solução pacífica das controvérsias internacionais, a hipótese do art. 36 se aproxima bastante da figura dos bons ofícios: por vontade própria, o Conselho de Segurança opta por se manifestar, devendo considerar que nenhuma de suas recomendações terá caráter vinculante para as Partes. Diz o art. 36(1):

The Security Council may, at any stage of a dispute of the nature referred to in art. 33 [the continuance of which is likely to endanger the maintenance of international peace and security] or of a situation of like nature, recommend appropriate procedures or methods of adjustment.

Tendo sido positivo o resultado das investigações e determinações de fatos, o Conselho poderá recomendar procedimentos ou métodos de adjustment apropriados à

\footnotetext{
${ }^{27}$ Naquela ocasião, a proposta americana previa a primazia do Conselho de Segurança na solução pacífica das controvérsias, autorizando inclusive o Conselho a tomar conhecimento ex officio de uma controvérsia com vistas a resolvê-la, ou seja, emitindo uma decisão acerca do problema. Tal proposta encontrou a objeção frontal do Reino Unido, sob a alegação de que o caráter vinculante das recomendações poderia ser prejudicial para alguns pequenos Estados. Os Estados Unidos insistiram em assegurar, pelo menos, que o Conselho de Segurança tivesse competência para determinar se as partes falharam ou não falharam na solução de uma controvérsia por meios bilaterais. O compromisso final consistiu na admissibilidade de ação ex officio do Conselho de Segurança, conquanto esta esteja limitada a emitir recomendações sem caráter vinculante. RUSSELL, R.; MUTHER, J. A history of the United Nations Charter. Washington: Brookings, 1958. p. 292-93.

${ }^{28}$ Id. Ibid., p. 663-64.
} 
solução, ainda que as Partes demonstrem algum empenho na aplicação do art. 33 (1) e estejam tentando resolver a controvérsia. Recomendar procedimentos ou métodos, que não são termos necessariamente sinônimos do ponto de vista jurídico, significa indicar às partes o caminho a seguir. Ou seja, o Conselho pode recomendar um meio específico de solução pacífica. Obviamente, o Conselho deverá, por força do disposto no art. 36 (2), "take into consideration any procedures for the settlement of the dispute which have already been adopted by the parties", de maneira a não-recomendar, por exemplo, o recurso à mediação do Secretário-Geral para uma controvérsia em que a mediação do ilustre funcionário já fracassou. No caso de existir uma controvérsia eminentemente jurídica, o Conselho não tem poderes para encaminhar tal matéria para a Corte. Todavia, fazendo uso de seus poderes conforme observa o art. 36 (3), pode determinar que as Partes se encaminhem para este tribunal:

In making recommendations under this article, the Security Council should also take into consideration that legal disputes should as a general rule be referred by the parties to the International Court of Justice in accordance with the provisions of the Statute of the Court. ${ }^{29}$

\section{Art. 37 (2). Conciliação}

A segunda modalidade de recomendação consiste na recomendação de termos específicos, a pedido de qualquer das Partes. Vimos que o art. 37 (1) cria um dever de interpelação do Conselho por qualquer das Partes tão logo se constate o fracasso na aplicação dos dispositivos do art. 33 (1). Tendo qualquer das partes interpelado o Conselho de Segurança nos termos do art. 37 (1), este deve agir de acordo com o disposto no art. 37 (2):

If the Security Council deems that the continuance of the dispute is in fact likely to endanger the maintenance of international peace and security, it shall decide whether to take action under Article 36 or to recommend such terms of settlement as it may consider appropriate.

\footnotetext{
${ }^{29}$ A prática do art. 36 (3) é bastante restrita, limitando-se a dois casos. Na célebre decisão sobre o Estreito de Corfu (Reino Unido v.s. Albânia), na Resolução n. 22 (1947), o Conselho entendeu adequado recomendar às partes o procedimento jurisdicional da CIJ. O Conselho tornaria a recomendar o recurso à CIJ no Caso do Mar Egeu (Turquia v.s. Grécia), pela Resolução n. 395 (1976). Já no Caso do Canal de Suez (França e Reino Unido v.s. Egito), o Conselho entendeu apropriado recomendar um procedimento arbitral às partes em sua Resolução n. 118 (1956). À exceção destes casos, a prática do Conselho tende a recomendar o recurso à negociação direta entre as partes, relembrando-as de seus compromissos internacionais face ao art. 2 (3) e art. 2 (4) da Carta das Nações Unidas.
} 
A ação do Conselho de Segurança no âmbito do art. 37 (2) é pautada pelo preenchimento dos requisitos encontrados neste artigo. Em primeiro lugar, é preciso analisar se a questão em debate constitui verdadeiramente uma controvérsia internacional. Textualmente, outras situações estão automaticamente afastadas da cobertura deste artigo. Constatada a existência da controvérsia, o Conselho deve se ater ao que diz o art. 37 (1) e procurar constatar a utilização e o fracasso dos outros meios de solução de controvérsia, conforme estabelecido pelo art. 33 (1). Superada mais esta preliminar, caberá ao Conselho verificar se sua competência não está excluída em vista do art. 2 (7), que trata dos assuntos de competência exclusiva dos Estados. Tendo em mãos uma controvérsia de caráter internacional, cujas partes fracassaram em solucionar, então o Conselho deverá analisar a real possibilidade de essa controvérsia constituir uma ameaça à manutenção da paz e da segurança internacionais.

$\mathrm{O}$ art. 37 (2) apresenta duas possibilidades de ação por parte do Conselho: a “action under Article 36”, que, como vimos, se restringe à recomendação específica de certos meios pacíficos considerados pertinentes à solução da controvérsia, inclusive o recurso à CIJ; e a recomendação de "such terms of settlement as it may consider appropriate", que é um pouco mais substanciosa e demonstra a possibilidade de atuação do Conselho de Segurança como conciliador em uma controvérsia.

O Conselho pode optar por recomendar os termos da paz ou indicar algum procedimento, levando sempre em consideração os esforços anteriormente tomados pelas partes. Nada exclui, porém, uma decisão mista. Assim, o Conselho poderá recomendar recurso a uma arbitragem internacional ou mesmo a uma negociação direta entre as partes conquanto sejam observadas determinadas condições. A opção de simplesmente recomendar procedimentos tende a adiar as soluções das controvérsias. É, no entanto, a que mais respeita as soberanias dos Estados, as demais sendo bastante objetadas pelas partes de uma controvérsia internacional.

\section{Art. 38. Conciliação ou mais além?}

A última modalidade de atuação do Conselho de Segurança no âmbito do Capítulo VI é a previsão contida no art. 38:

Without prejudice to the provisions of Articles 33 to 37, the Security Council may, if all the parties to any dispute so request, make recommendations to the parties with a view to a pacific settlement of the dispute. 
Ora, se as partes estão obrigadas a solucionar pacificamente as suas controvérsias, e estão autorizadas a fazer uso de qualquer meio pacífico para obterem tal solução, nada impede que as partes optem por submeter sua controvérsia ao julgamento político do Conselho de Segurança, para que este faça suas recomendações, solucionando assim a controvérsia.

Mas o art. 38 oferece duas interpretações distintas. Como não se faz nenhuma restrição quanto à natureza da controvérsia, efetivamente qualquer uma ( "any”) poderia ser oferecida à apreciação do Conselho, mesmo aquelas que não se enquadram na qualificação do art. 33 (1). Uma outra interpretação possível considera que o art. 38 pode ser aplicado apenas para controvérsias que não se enquadrem no art. 33 (1), ou seja, que claramente não constituam ameaça à paz e à segurança internacionais. A segunda interpretação tecnicamente justificaria a necessidade de todas as partes solicitarem a atuação do Conselho: uma tal controvérsia só mereceria ser posta na pauta do Conselho de Segurança conquanto as partes acreditassem se tratar de algo cuja crucial pacificação necessita a intervenção do Conselho. Ademais, a redação do artigo faculta ( "the Security Council may") ao Conselho a manifestação de qualquer recomendação às partes. Ao contrário do que ocorre no art. 37 (2), o Conselho não está obrigado a tomar qualquer decisão: permite-se, portanto, que o Conselho se recuse a participar na solução da controvérsia que lhe é apresentada. Este é o motivo principal pelo qual o art. 38 é pouquíssimo utilizado. ${ }^{30}$

De qualquer maneira, caso interpelado por todas as partes de uma controvérsia conforme o texto do art. 38, e caso o Conselho decida manifestar-se, sua manifestação não se limitará à recomendação de procedimentos, mas sim à recomendação de termos e condições para a solução da controvérsia. Nada impede que as partes estabeleçam entre si o caráter obrigatório da decisão do Conselho para o caso específico que estejam a ele submetendo. É lícito supor que um recurso concorde ao Conselho de Segurança demande um compromis a esse respeito ou pelo menos algum esboço de compromisso prévio, e que as partes estejam efetivamente dispostas a aceitar a decisão do Conselho. A escassez da prática inutiliza o dispositivo e transforma em ocultismo jurídico a ponderação sobre seus efeitos.

\footnotetext{
${ }^{30}$ Nenhum país do mundo jamais requereu a atenção do Conselho de Segurança fazendo menção ao art. 38 da Carta. Todavia, a prática do Conselho tende a reconhecer que, quando as partes encaminham por conta própria queixas referentes à solução de controvérsias, o Conselho deverá se considerar interpelado nos termos do art. 38 . Entre os exemplos clássicos dessa interpretação, destaca-se a controvérsia entre hindus e muçulmanos por ocasião da formação da Índia e do Paquistão, e os conflitos que se seguiram à separação oficial das duas ex-colônias britânicas. Todavia, tanto Índia quanto Paquistão pretenderam interpelar o Conselho com base no art. 35 (1).
} 
A redação do art. 38, como a redação do art. 37 (2), permite ao Conselho tomar decisões que não estejam de acordo com o Direito Internacional e isso pode causar uma série de inconvenientes. As decisões do Conselho são limitadas, nos termos do art. 24 (2) da Carta, a estarem de acordo com os propósitos e princípios da Carta das Nações Unidas. Afora isso, e a limitação posta pelo art. 37 (2) ("terms of settlement as it may consider appropriate"), o Conselho é livre para decidir o que quiser "in conformity with the principles of justice and international law”. Se os princípios da justiça e as regras positivas do Direito Internacional muitas vezes colidem, o Conselho de Segurança pode tomar uma decisão justa que contrarie princípios de Direito Internacional, se assim considerar apropriado ou, note-se bem, o Conselho poderá tomar uma decisão flagrantemente injusta que esteja perfeitamente fundamentada de acordo com o Direito Internacional positivo. ${ }^{31}$

Uma recomendação vinculante - ou seja, uma decisão - poderia criar novos direitos ou novas obrigações jurídicas na relação entre as Partes, o que de maneira alguma o Conselho de Segurança está autorizado a fazer. Assim, qualquer recomendação de termos só terá força de lei caso as Partes concordem em cumprí-la com vistas a resolver pacificamente a controvérsia. ${ }^{32}$

\footnotetext{
${ }^{31}$ O significado desse tipo de previsão, aparentemente contrária ao espírito pacifista de Dumbarton Oaks e da Carta do Atlântico, tem em vista autorizar o Conselho a recomendar termos que possam suplantar os direitos que, nos termos da lei, uma ou outra parte possa ter adquirido. Tal atitude se reveste de um caráter político inegável e deve ser entendida à luz do que a própria Carta explicita: o Conselho tem como função primordial assegurar a manutenção da paz e da segurança internacionais e para tal fim deve modular sua atuação de maneira que os princípios da justiça e do Direito Internacional contribuam de modo efetivo para tanto, ainda que em contextos diferentes. Não é por outro motivo que a Carta fala em condições apropriadas à solução das controvérsias internacionais, e confere ao Conselho caráter discricionário para determinar a pertinência de uma dada decisão conforme o Direito Internacional ou os princípios da justiça. Se a decisão é justa ou injusta, legal ou ilegal, legítima ou ilegítima, inapropriada ou apropriada, caberá unicamente ao Conselho de Segurança considerar tais fatores em sua decisão. Por produzir mudanças na ordem internacional sem o derramamento obrigatório de sangue, tal possibilidade ilustra a faceta do pilar menos conhecido dos mecanismos de prevenção da guerra: os mecanismos de mudança pacífica. H. Kelsen exemplifica: uma cessão territorial ordenada pelo Conselho pode não ter nenhuma justificativa jurídica, e pode não ser amparada por nenhum tratado internacional. Isso não a torna injusta. Estando revestida da forma prevista pela Carta das Nações Unidas, terá caráter obrigatório para ambas as Partes e, tendo em vista o sistema de funcionamento do Conselho, provavelmente contribuirá para a solução ou ajuste da controvérsia ou situação. KELSEN, H. op. cit. p. 386.

${ }^{32}$ Id. Ibid. p. 446.
} 


\subsubsection{Mecanismos Regionais}

Além das opções vistas até o momento, a Carta das Nações Unidas oferece outro dispositivo destinado a complementar as possibilidades de solução pacífica das controvérsias internacionais a partir de ações regionais. Tal dispositivo se insere no Capítulo VIII da Carta, intitulado 'Acordos Regionais'. O extenso art. 52 prevê em seu parágrafo primeiro que nada na Carta impedirá a existência de "regional arrangements or agencies" para lidar com temas relacionados à manutenção da paz e da segurança internacionais, "as are appropriate for regional action".

A condição que a Carta cria para cooperação com as instituições regionais reside no próprio texto do art. 52 (1). De um lado, requer-se a viabilidade institucional de um trato regional ao assunto, ou seja, que as partes estejam todas submetidas ao mesmo acordo de solução pacífica, ainda que não exista o elemento geográfico de sua regionalidade. De outro, exige-se que "such arrangements or agencies and their activities are consistent with the Purposes and Principles of the United Nations", ou seja, exige-se que não se abra mão das finalidades da ONU, tampouco das obrigações dos membros contidas na Carta. O efeito imediato dessa medida é a necessidade de que conste nos estatutos regionais algum mecanismo de solução pacífica de controvérsias que justifique sua utilização.

Além dessas considerações de ordem geral, o art. 52 estabelece obrigações de conduta para os Membros das Nações Unidas e para o Conselho de Segurança. O art. 52 (2) estabelece que os Membros das Nações Unidas que façam parte de algum mecanismo regional devem se esforçar para "achieve pacific settlement of local disputes" através de tais mecanismos. Mais do que isso, o art. 52 (2) determina que o esforço regional deve ser realizado antes de as Partes encaminharem a matéria para o Conselho de Segurança. Ora, isto colide com o princípio da livre-escolha de meios, consagrada pelo art. 33 (1) da Carta. O art. 52 (2) parece, portanto, interpor-se como uma limitação à liberdade das Partes. Mas o art. 52 (2) só poderá ser implementado à medida que os mecanismos regionais regulamentem sua atividade no campo da solução pacífica de controvérsias. E a implementação de um mecanismo regional para solução de controvérsias exige que as Partes produzam algum tipo de entendimento regional acerca da matéria ao qual deveriam priorizar, posto que se preocuparam em produzi-lo não-obstante o sistema universal representado pela Carta das Nações Unidas. Em síntese, conforme sejam formadas alternativas regionais para a solução de controvérsias internacionais, estas alternativas 
tendem a se impor como prioritárias, de modo a permitir que a realidade regional e suas possibilidades relativas possam ser empregadas em benefício da paz mundial.

$\mathrm{O}$ art. 52 (2) demonstra a ambigüidade do relacionamento das Nações Unidas com suas alternativas regionais para manutenção da paz e da segurança internacional. Se aparentemente a idéia era demonstrar que o recurso aos mecanismos regionais não viola a Carta das Nações Unidas, de outro lado não é coerente com o espírito dos demais capítulos da Carta o esvaziamento do papel das Nações Unidas no campo da manutenção da paz e da segurança internacionais. Um passo além nesse campo ambíguo é a obrigação que a Carta estabelece para o Conselho de Segurança. O art. 52 (3) determina que o Conselho deverá encorajar o desenvolvimento de mecanismos regionais para a solução das controvérsias regionais através de acordos regionais e organizações regionais "either on the initiative of the states concerned or by reference from the Security Council”. Por um lado não deverá impedir os Estados de recorrerem a mecanismos regionais se estes assim convierem; por outro, abre-se a possibilidade de o Conselho recomendar às Partes a solução regional nos termos do art. 36 (1) mesmo que os Estados não a queiram.

$\mathrm{O}$ art. 52 (4) complementa a matéria afirmando que o art. 52 não prejudica a aplicação dos arts. 34 e 35. Com isso, o Conselho de Segurança preserva para si a competência para determinar a natureza regional de uma controvérsia. Respeitam-se ainda os dispositivos referentes à ativação das prerrogativas do Conselho, podendo deste modo o Conselho intervir em controvérsias regionais que estejam sendo tratadas de modo inadequado pelas partes. O total poder discricionário do Conselho de Segurança permanece intacto, estando concordes os Membros permanentes.

O grande problema para a aplicação do art. 52 é justamente a articulação dos entendimentos institucionais entre os acordos e organizações regionais e as Nações Unidas. Como a Carta procura estimular a prática regionalista sem desmoralizar as prerrogativas do Conselho de Segurança, não há uma clara delimitação hierárquica, tampouco uma repartição de competências. Não havendo a obrigação de esgotar os meios regionais antes de se recorrer ao Conselho, existe a possibilidade de estabelecer dupla intervenção em determinadas controvérsias sem que isso contribua para a efetiva solução da mesma. Outro problema é a necessidade de adaptação dos estatutos regionais, os quais demandam negociações nem sempre tranqüilas.

Entre os mecanismos regionais, merecem destaque a Organização dos Estados Americanos (OEA), a antiga Organização da Unidade Africana (OUA), agora chamada União Africana (UA), e a Liga dos Estados Árabes (LEA), com resultados bastante díspares. De um modo geral, as relações institucionais entre as Nações Unidas 
e estas três organizações regionais têm variado bastante. O fim da União Soviética deu aos Estados Unidos a oportunidade de fortalecer sua posição hegemônica no Ocidente. $\mathrm{O}$ desenvolvimento de alternativas informais latino-americanas à OEA para solução dos problemas regionais, lideradas principalmente pelo Brasil e pelo México, e mais recentemente pela Venezuela, e os problemas específicos da política externa americana frente ao Oriente Médio, têm contrabalançado essa hegemonia. Por outro lado, a relação entre a Liga Árabe e a ONU é bastante morna, talvez devido ao apoio quase incondicional dos Estados Unidos a Israel. Já as relações com a União Africana são bastante frutíferas, principalmente na Assembléia Geral, onde os países africanos contabilizam 54 votos. Mais de uma resolução da Assembléia Geral saúda a União Africana em seus esforços para pacificação do continente.

\subsection{A Assembléia Geral das Nações Unidas}

A Assembléia Geral das Nações Unidas é o único dos órgãos principais das Nações Unidas no qual todos os Estados-Membros estão representados por seus respectivos corpos diplomáticos. Essa observação é importante, pois não devemos vê-la como um parlamento mundial dos povos, mas como uma grande conferência intergovernamental onde os Estados tomam decisões que, in extremis, se destinam a preservar o princípio da igualdade soberana em face dos desafios da globalidade. Graças à sua ampla composição, a Assembléia Geral é o mais importante fórum mundial de discussões políticas intergovernamentais da atualidade.

\subsubsection{Competência-Geral}

A letra da Carta das Nações Unidas confere à Assembléia Geral as mais variadas funções que buscam justificar sua posição de órgão cimeiro das Nações Unidas. No que tange ao tema da solução pacífica de controvérsias, as competências da Assembléia Geral assemelham-se às do Conselho de Segurança, embora estas mereçam detalhamento maior que aquelas no âmbito do Capítulo VI. Estabelecidas em termos genéricos pela Carta, as competências da Assembléia Geral foram construídas a partir de suas resoluções, sempre visando suprir as deficiências do Conselho de Segurança e estabelecer os parâmetros de cooperação entre os membros.

$\mathrm{O}$ art. 10 da Carta das Nações Unidas estabelece, de modo bastante amplo, os poderes da Assembléia Geral nos seguintes termos: 
The General Assembly may discuss any questions or any matters within the scope of the present Charter or relating to the powers and functions of any organs provided for in the present Charter, and, except as provided for in Article 12, may make recommendations to the Members of the United Nations or to the Security Council or to both on any such questions or matters.

Decorre deste artigo a noção de que a Assembléia Geral possui uma competência-geral para discutir e fazer recomendações acerca de qualquer matéria que envolva os propósitos e princípios da Carta das Nações Unidas.

Claro está, todavia, que uma competência de tal maneira alargada daria margem para que a Assembléia Geral incluísse em sua pauta praticamente todas as mazelas do planeta, como de fato procura incluir. Por causa disso, o próprio art. 10 traça os limites dessa competência-geral, condicionando-a ao disposto no art. 12 (1), segundo o qual a Assembléia Geral não pode fazer recomendações sobre assuntos concernentes à manutenção da paz e da segurança internacionais enquanto o Conselho de Segurança estiver exercendo suas prerrogativas sobre a matéria. De acordo com o art. 12 (2), o Secretário-Geral deve manter a Assembléia Geral informada quanto às pautas do Conselho de Segurança. Para evitar ingerências, o Conselho de Segurança geralmente encerra as suas resoluções com uma cláusula-padrão segundo a qual "decides to remain actively seized of the matter". Assim, o Conselho preserva a sua primazia e impede que a Assembléia Geral aprove resoluções que possam colocar em risco as decisões já tomadas e as negociações conduzidas até então.

Uma segunda limitação ao exercício das amplas competências da Assembléia Geral pode ser encontrada no art. 11 (2) in fine, segundo o qual qualquer questão "on which action is necessary” deve ser encaminhada ao Conselho de Segurança pela Assembléia Geral antes ou depois de ser discutida. Mais uma vez, a Carta condiciona a ação (aqui entendida como a aplicação direta do Capítulo VII) à concordância dos Membros-Permanentes, evitando que a maioria silenciosa dos pequenos países conduza ações militares sem a aquiescência dos Grandes Poderes. Mais do que isso, levando em conta o papel preponderante que a própria Carta confere ao Conselho, há que se falar em coerência do sistema de segurança coletiva, conforme concebido, em 1945, o qual poderia se degenerar rapidamente se deixado nas mãos de um órgão tão "igualitário" quanto a Assembléia. ${ }^{33}$

\footnotetext{
33 Apesar de igualmente soberanos, os Estados são muito assimétricos em matéria de poderio militar, contingente populacional, recursos energéticos, instituições internas, enfim, em praticamente todos os quesitos materiais
} 


\subsubsection{Competências Específicas}

Os poderes específicos da Assembléia Geral com referência à solução pacífica de controvérsias podem ser encontrados no arts. 11 (2, 3), 13 e 14. Antes de tudo, é importante observar, tendo em vista o caráter plenário da Assembléia Geral, que este é um órgão que não dispõe - em tese - de vocação para instância de solução de controvérsias internacionais, caracterizando-se muito mais por sua condição de tribuna política internacional que por seu perfil técnico ou mesmo imparcial. É evidente que não se pode exigir imparcialidade de um órgão político. Tampouco é imparcial o Conselho de Segurança, onde as Grandes Potências primeiro garantem seus interesses nacionais e depois se preocuparem com os interesses da Comunidade Internacional. Mas, contra todas as probabilidades, as intervenções da Assembléia Geral tendem a produzir efeitos positivos, uma vez que seu processo decisório se qualifica por um respeito rígido à igualdade soberana dos Estados, não havendo poder de veto por parte dos MembrosPermanentes do Conselho de Segurança.

$\mathrm{O}$ art. 11 (2) autoriza a Assembléia Geral a discutir "any questions relating to the maintenance of international peace and security brought before it". É, essencialmente, uma especificação do disposto no art. 10, estabelecendo a competência específica da Assembléia Geral para lidar com questões referentes à manutenção da paz e da segurança internacional, o que, aliás, colide frontalmente com a idéia geral do art. 24 da Carta, segundo o qual cabe ao Conselho de Segurança exercer a primazia quanto à manutenção da paz e da segurança internacional. Esse paralelismo aberto pela Carta das Nações Unidas demonstra que o Conselho de Segurança, conquanto seja o primaz, não é o órgão exclusivo para solução de controvérsias no âmbito das Nações Unidas, o que, como já havíamos observado, demonstra o respeito à aplicação do princípio da livre-escolha de meios de solução pacífica.

Podem trazer tais questões à Assembléia Geral, nos termos do próprio art. 11 (2), os Membros da ONU e os não-membros, nos mesmos termos do art. 35 (2). Pode ainda a Assembléia Geral ser acionada pelo próprio Conselho de Segurança. A relação entre a Assembléia Geral e o Conselho de Segurança no exercício da solução pacífica de controvérsias é complementar, pois, como observa o art. 11 (3), também a Assembléia

em que se deseje compará-los. Assim, a maioria qualificada necessária para a aprovação de uma resolução da Assembléia Geral não simboliza necessariamente a vontade majoritária dentre os detentores do poder ou dentre os representantes das maiores parcelas da humanidade. Por isso, a Assembléia Geral se vê, inicialmente, privada de tomar decisões referentes à aplicação de medidas coercitivas sem aprovação expressa das Grandes Potências. 
Geral pode chamar a atenção do Conselho de Segurança para "situations which are likely to endanger international peace and security", o que impede ou ao menos dificulta a manipulação da pauta do Conselho de Segurança por seus Membros.

A escolha de palavras do art. 11 demonstra a diferença entre os mandatos da Assembléia Geral e o Conselho de Segurança. Enquanto cabe ao Conselho a principal responsabilidade pela manutenção da paz e da segurança internacionais, devendo este órgão tomar decisões acerca de controvérsias ou outras situações que possam colocar em risco a paz e a segurança internacional, cumpre à Assembléia Geral manifestar-se acerca de qualquer questão relacionada ao tema. É claro que isso inclui a discussão de controvérsias internacionais e outras situações, mas inclui principalmente as questões preventivas, para as quais a competência primária do Conselho de Segurança não é aplicável.

Assim, uma análise pragmática do art. 11 faz notar que situações que ameacem a paz e a segurança internacionais devem ser levadas pela Assembléia ao Conselho enquanto a discussão de assuntos mais gerais, ou menos urgentes, tais como a elaboração de declarações que sistematizem algum aspecto da manutenção da paz e da segurança internacionais podem ser solicitadas pelo Conselho à Assembléia, nãoapenas para aliviar a agenda daquele órgão, mas para the assegurar melhor desempenho no exercício de sua tarefa primeira de manutenção da paz e da segurança internacionais. A competência da Assembléia Geral é, portanto, suplementar à do Conselho de Segurança neste campo.

Uma demonstração dessa vocação preventiva da Assembléia Geral é o art. 13 da Carta, o qual estabelece o poder da Assembléia Geral para conduzir estudos e fazer recomendações com o objetivo de: (i) promover a cooperação internacional no campo político; (ii) encorajar o desenvolvimento progressivo do Direito Internacional e sua codificação; (iii) promover a cooperação internacional nos campos político, econômico, social, cultural e da saúde; (iv) ajudar na realização dos direitos humanos e das liberdades fundamentais para todos sem distinções raciais, étnicas, religiosas ou de gênero. O volume de trabalho da Assembléia Geral neste campo é imenso e se relaciona com a prevenção de controvérsias internacionais através da satisfação permanente dos interesses individuais dentro de cada Estado, na medida em que tais práticas de cooperação internacional desestimulam rixas históricas e esvaziam o potencial de atrito de algumas regiões.

Estando ciente de uma dada questão, a Assembléia poderá, nos termos do art. 11 (2) "make recommendations with regard to any such questions to the state or states concerned or to the Security Council or to both ”. Assim, a Assembléia Geral poderá se manifestar na forma de uma recomendação semelhante às do Conselho de Segurança 
tomadas no âmbito do Capítulo VI. A recomendação será dirigida aos Estados envolvidos, ao Conselho de Segurança ou a ambos. Mas não se deve subestimar uma recomendação da Assembléia Geral, que possui uma força moral intrínseca bastante expressiva, que pode mesmo ser decisiva na solução de uma controvérsia.

\subsection{O Secretariado}

Finalmente, o último dos órgãos principais da ONU relacionado ao tema da solução de controvérsias: o Secretariado. Regido principalmente pelos dispositivos do Capítulo XV da Carta, o Secretariado é composto de um Secretário-Geral, principal funcionário administrativo da ONU, indicado pela Assembléia Geral mediante recomendação por parte do Conselho de Segurança, e de um corpo técnico de servidores civis internacionais nomeados pelo Secretário-Geral tendo em vista as regras estabelecidas pela Assembléia Geral à luz dos mais elevados padrões de eficiência, competência e integridade e da mais ampla representatividade geográfica possível. É um pressuposto de conduta do Secretário-Geral e de seu staff que estes não devam procurar ou aceitar instruções de qualquer governo ou autoridade alheia à Organização. De acordo com o art. 100 (2), os Membros das Nações Unidas se comprometem a respeitar o caráter exclusivamente internacional das responsabilidades do Secretário-Geral e de seu staff, não procurando influenciá-lo no exercício de suas atribuições.

No campo da solução pacífica de controvérsias internacionais, as atribuições do Secretariado são, em larga medida, atribuições pessoais do Secretário-Geral, estabelecidas pelos arts. 98 e 99. Nos termos do art. 98, o Secretário-Geral deve participar - diretamente ou por seus substitutos - em todos os encontros da Assembléia Geral, do Conselho de Segurança, do Conselho Econômico e Social e do Conselho de Tutela, e desempenhar todas as funções que estes órgãos venham a lhe determinar, apresentando anualmente à Assembléia Geral um relatório sobre os trabalhos da Organização, no qual expõe uma revisão geral de todas as atividades conduzidas pelos órgãos das Nações Unidas, analisa qualitativamente o desempenho de cada órgão e da organização como um todo e propõe modos de aprimorar esse trabalho. Tais necessidades requerem uma estrutura cada vez maior e põem em risco a eficiência no exercício das atribuições tanto do ponto de vista funcional quanto do ponto de vista orçamentário. É por meio do Secretário-Geral e seu 
sempre crescente staff que as Nações Unidas cumprem o que lhes cabe das resoluções e decisões de seus órgãos principais. ${ }^{34}$

Uma síntese das funções que o secretário-geral desempenha, direta ou indiretamente, incluiria as seguintes atribuições: (i) apresentar as comunicações dos governos para as Nações Unidas e vice-versa; (ii) conduzir discussões e consultas com as Partes e com demais Membros interessados; (iii) liderar procedimentos para determinação de fatos; (iv) participação e apoio na condução de negociações entre as Partes de uma controvérsia com vistas a uma solução pacífica ou a implementação de um acordo de paz anterior. $^{35}$

\section{Considerações finais}

A análise objetiva do sistema de solução pacífica das controvérsias no âmbito das Nações Unidas demonstra o papel proeminente conferido ao Conselho de Segurança e, conseqüentemente, à idéia do consenso entre as Grandes Potências e, portanto, à idéia de conservação das estruturas de poder. Consideramos indispensável o papel desempenhado pelo Conselho de Segurança no tema. Todavia, a institucionalização de qualquer órgão para desempenhar tal tarefa, requer uma melhor construção jurídica. A atual redação da Carta das Nações Unidas contém erros e dubiedades que tornam a prática do Conselho de Segurança vulgarmente casuística, e a casuística vulgar permite a aplicação de dois pesos e duas medidas para casos que se assemelham.

São Paulo, abril de 2007.

\footnotetext{
${ }^{34}$ No repertório de ações do secretário-geral por mandato conferido pela Assembléia Geral, no que tange à negociação de acordos de paz, merecem destaque suas atuações na China (1953), Palestina (1956), Irã, Paquistão e Afeganistão (1980) e novamente no Afeganistão em 1993. Por ordem do Conselho de Segurança, vasta gama de resoluções estabelece funções a serem cumpridas pelo secretário-geral, entre as quais destacamos a Resolução n. 218 (1965) referente ao conflito indo-paquistanês, a Resolução n. 242 (1967), referente à situação no Oriente Médio, a Resolução n. 348 (1974) referente ao conflito entre Irã e Iraque, a Resolução n. 620 (1988) referente à violação do protocolo de Genebra, a Resolução n. 674 (1990), referente aos reféns no Iraque e, mais recentemente, nos esforços de pacificação da África Central, especialmente Ruanda, Burundi, Uganda e Congo.

35 Assim, em 1965, durante a crise política que abateu a República Dominicana, o secretário-geral sugeriu ao governo dos Estados Unidos que oferecessem seus bons ofícios para dirimir a controvérsia. Em 1980, na controvérsia entre Líbia e Malta, o secretário-geral conduziu as consultas entre os governos através de um representante por ele designado. É importante observar que a autoridade moral de que goza o secretário-geral não é uma versão laica da autoridade moral reconhecida ao Papa durante a Idade Média, ou seja, o secretáriogeral não é uma autoridade supragovernamental com suporte teológico, apenas um diplomata extremamente qualificado. Deve servir como mediador, nunca como árbitro. Para resoluções vinculantes, a ONU dispõe de sua Corte Internacional de Justiça e, nos termos do art. 38 e do Capítulo VII, do Conselho de Segurança das Nações Unidas.
} 


\section{Referências}

ACCIOLY, Hildebrando. Tratado de direito internacional público. Rio de Janeiro: MRE, 1957.

ACCIOLY, Hildebrando; SILVA, Geraldo Eulálio do Nascimento e; CASELLA, Paulo Borba. Manual de direito internacional público. São Paulo: Saraiva, 2006.

AKEHURST, Michael Barton. A modern introduction to international law. Londres: Allen \& Unwin, 1970.

ARANGIO-RUEZ, Gaetano. The normative role of the General Assembly of the United Nations and the Declaration of Principles of Friendly Relations. Recueil des Cours, v. 137, n. 3, p. 419-742, 1972.

AZUD, Ján. The peaceful settlement of disputes and the United Nations. Bratislava: Academia Eslovaca de Ciências, 1970.

BEIRLAEN, A. La distinction entre les différends juridiques et politiques dans la pratique des organisations internationales. Revue Belge de Droit International, v. 11, p. 405-41, 1975

BOBBIO, Norberto. O problema da guerra e as vias da paz. São Paulo: UNESP, 2003. . Dicionário de Política. Brasília: UnB, 2004.

. El tercero ausente. Madrid: Catedra, 1997. . Teoria geral da política. São Paulo: Campus, 2002.

BOWETT, Derek. The Impact of Security Council Decisions on Dispute Settlement Procedures. European Journal of International Law, v. 5, n. 1, p. 89-101, 1995.

BROWNLIE, Ian. Principles of public international law. Oxford: Oxford University Press, 1998.

BRUGIÈRE, Pierre. Les Pouvoirs de l'Assemblée Générale des Nations Unies en Matière Politique et de Sécurité. Paris: Pédone, 1955.

CASSESE, Antonio. International law in a divided world. Oxford: Oxford University Press, 1986. CONFORTI, Benedetto. Le Nazioni Unite. Pádua: CEDAM, 1979.

COT, Jean-Pierre; PELLET, Alain. Le Charte des Nations Unies: Commentaire article par article. Paris: Economica, 1991.

DAY, Georges. Le Droit de Veto dans l'Organisation des Nations Unies. Paris: A. Pedone, 1952. 
ECONOMIDÈS, Constantin. La Déclaration de Manille sur le Règlement Pacifique des Différends Internationaux. Annuaire Français de Droit International, v. 28, p. 613-27, 1982.

FRIEDMANN, Wolfgang. The Changing Structure of International Law. Nova York: Columbia, 1964.

GOODRICH, Leland Matthew; HAMBRO, Edward; SIMONS, Anne Patricia. Charter of the United Nations: Commentary and Documents. Nova York: Columbia, 1969.

GOODRICH, Leland Matthew; SIMONS, Anne Patricia. The United Nations and the Maintenance of International Peace and Security. Washington: Brookings, 1955.

HERNDL, Kurt. Reflections on the role, functions and procedures of the Security Council of the United Nations. Recueil des Cours, v. 206, n. 6, p. 289-395, 1987.

HIGGINS, Rosalyn. The place of international law in the settlement of disputes by the Security Council. American Journal of International Law, v. 64, p. 1-18, 1970.

HOIJER, Olof. Solution Pacifique des Litiges Internationaux. Paris: Spes, 1925.

JIMÉNEZ DE ARÉCHAGA, Eduardo. Derecho Constitucional de las Naciones Unidas. Madrid: Escuela de Funcionarios Internacionales, 1958.

. Le traitement des différends internationaux par le Conseil de Sécurité. Recueil des Cours, v. 85, n.1, 5-103, 1974.

. Voting and the handling of disputes in the Security Council. Nova York: Carnegie Endowment for International Peace, 1950.

KELSEN, Hans. The law of the United Nations. Londres: Stevens, 1950.

. Teoria geral do direito e do estado. São Paulo: Martins Fontes, 2004.

Teoria pura do direito. São Paulo: Martins Fontes, 2004.

KERLEY, Ernest. The Powers of Investigation of the United Nations Security Council. American Journal of International Law, v. 55, p. 918-982, 1961.

KISSINGER, Henry. Diplomacy. Nova York: Touchstone, 1995.

. Mundo restaurado. Rio de Janeiro: José Olympio, 1973.

MAGALHÃES, José Carlos de; MERCADANTE, Araminta de Azevedo (Org.). Solução e prevenção de litígios internacionais. São Paulo: CAPES, 1998. 
MEITANI, R. Le Règlement Pacifique des Litiges Internationaux selon la Charte des Nations Unies. Revue International Française du Droit des Gens, v. 16, p. 5-201, 1947.

MELLO, Celso D. de Albuquerque. Curso de Direito Internacional Público. Rio de Janeiro: Renovar, 2003.

MERRILS, John Graham. International Dispute Settlement. Cambrige: Cambridge University Press, 1998.

MONACO, Riccardo. Manuale di diritto internazionale pubblico. Torino: Utet, 1977.

NORTHEDGE, Frederick; DONELAN, Michael. International Disputes - The Political Aspects. Londres : Europa, 1971.

NGUYEN, Quoc Dinh; DAILlER, Patrick; PELLET, Alain. Direito Internacional Público. 2. ed. Lisboa: Fundação Calouste Gulbenkian, 2003.

PATIL, Anjali V. The UN veto in world affairs, 1946-1990: a complete record and case histories of the Security Council's veto. Londres: Mansell, 1992.

PATRIOTA, Antonio de Aguiar. O Conselho de Segurança após a Guerra do Golfo: a articulação de um novo paradigma de segurança coletiva. Brasília: FUNAG, 1998.

RAMAN, K. Venkata (Ed.). Dispute Settlement through the United Nations. Nova York: Oceana, 1977.

RANGEL, Vicente Marotta. Do conflito entre a Carta das Nações Unidas e os demais acordos internacionais. São Paulo: Saraiva, 1954.

REZEK, José Francisco. Direito Internacional Público: curso elementar. São Paulo: Saraiva, 2003.

ROSS, Alf. Constitution of the United Nations: analysis of structure and function. Nova York: Rinehart, 1950.

. United Nations - peace and progress. Nova Jersey: Bedminster, 1966.

ROUSSEAU, Charles. Droit international public. Paris: Sirey, 1983.

RUSSELL, Ruth B.; MUTHER, Jeannette. E. A history of the United Nations Charter. Washington: Brookings, 1958.

SALOMON, André. L'ONU et la paix: le Conseil de Sécurité et le Règlement Pacifique des Différends. Paris: Internationales, 1948. 
SCHACHTER, Oscar. The quasi-judicial role of the seucrity council and the general assembly. American Journal of International Law, v. 58, p. 960-6, 1964.

SHAW, Malcolm. International law. Cambridge: Grotius Publications, 1991.

SIMMA, Bruno. The Charter of the United Nations: a commentary. Oxford: Oxford University Press, 1995.

SOARES, Guido Fernando Silva. Curso de Direito Internacional Público. 2. ed. São Paulo: Atlas, 2004.

SOHN, Louis. The Security Council's Role in the Settlement of International Disputes. American Journal of International Law, v. 78 (1984).

TEIXEIRA, Pascal. Le conseil de sécurité à l'aube de XXI siècle: quelle volonté et quelle capacité a-t-il de maintenir la paix et la sécurité internationales? Genebra: UNIDIR, 2002.

TREVES, Tullio. La Prévention des Conflits Internationaux dans la Déclaration adoptée en 1988 par l'Assemblée Générale des Nations Unies. Annuaire Français de Droit International, v. 34, p. 436-53, 1988.

UNITAR (Ed.). The United Nations and the Maintenance of International Peace and Security. UN Doc. UNITAR/St./20, 1987.

UNITED NATIONS. Handbook on the Peaceful Settlement of Disputes between States. Nova York: United Nations Publications, 1992.

VALLAT, Francis Aimé. The competence of the United Nations General Assembly. Recueil des Cours, v. 97, n. 2, p. 203-292, 1959.

VILLANI, Ugo. Les rapports entre l'ONU et les organisations régionales dans le domaine du maintien de la paix. Recueil des Cours, v. 290, p. 225-436, 2001.

VIRALLY, Michel. L'Organisation Mondiale. Paris: A. Collin, 1972.

VISSCHER, Charles de. Théories et réalités en droit international public. Paris: Pedone, 1970.

WALDOCK, Sir Humphrey. International Disputes: the Legal Aspects. Londres: Europa, 1972. 